\title{
ТАКТИКА ЛІКУВАННЯ ХВОРИХ НА ГОСТРИЙ ПЕРИТОНІТ
}

\section{А.Ф. Гринчук}

ВДНЗ України «Буковинський державний медичний університет», кафедра хірургії № 1, м. Чернівиі, Украӥна, ORCID ID: 0000-0001-6636-6855, e-mail: grynchuk.andrii@bsmu.edu.ua

Резюме. Вдосконалення тактики лікування хворих на гострий перитоніт (ГП) наразі залишається актуальною проблемою, що зумовлено високою летальністю.

Метою роботи було попереднє оцінювання ефективності напрацьованої тактики лікування хворих на ГВК.

Матеріали та методи. 60 хворих, з яких місцевий ГП виявлений у 12 (20\%) хворих, дифузний - у 15 (25), розлитий - у 17 (28,33\%), загальний - у 16 (26,67\%). Ретроспективний аналіз результатів лікування 169 хворих на різні форми ГП. У 79 з них були післяопераційні ускладнення. Померли 39 хворих. Лікування хворих проводили з використанням напрацьованого алгоритму.

Результати. Основою вибору тактики є розроблена прогностична шкала, що передбачає попередній і основний етапи прогнозування. У хворих середнього і високого ризику розширюємо показання до передопераційного підготування. Основне оцінювання проводимо протягом операції. Диференційовано застосовуємо комплекс інтраопераційних і післяопераційних заходів. Розширюємо показання до використання заходів 3 профілактики ускладнень, запрограмованих санацій очеревинної порожнини, застосовуємо розроблені методи санації. 3 використанням такої тактики нами проліковано 24 хворих. Знизилася на 18,18\% кількість інтраабдомінальних інфільтратів. Скоротилася на 2,5 дні тривалість стаціонарного лікування. Не помер жоден хворий.

Висновки. Застосування розробленого алгоритму, що заснований на виділенні груп звичайного, збільшеного, середнього і високого ризику розвитку ускладнень, дозволяє визначати тактику лікування хворих і коректувати медикаментозний комплекс. Клінічна апробація алгоритму свідчить про його ефективність і доцільність наступного широкого впровадження в практику.

Ключові слова: гострий перитоніт, прогнозування ускладнень, тактика лікування.

Вступ. Вдосконалення тактики лікування хворих на гострий перитоніт наразі залишається актуальною проблемою. Незважаючи на постійне вдосконалення лікувальних настанов [1-8], летальність за поширеного гострого перитоніту сягає $30-70 \%$ $[2,4,7,9,10]$. Це свідчить про необхідність вдосконалення тактики лікування.

Обгрунтування дослідження. Відомі настанови $з$ лікування гострого перитоніту містять низку суперечностей. Зокрема, контраверсійними залишаються погляди на поширеність перитоніту, оцінювання тяжкості, прогнозування перебігу, неоднозначно оцінюють показання до передопераційного приготування, проведення запрограмованих санацій очеревинної порожнини, суттєво відрізняються рекомендації щодо методів санації, медикаментозного лікування [1-8,11].

Мета роботи. Провести попередне оцінювання ефективності напрацьованої тактики лікування хворих на гострий перитоніт.

Матеріали та методи. Обстежено 60 хворих віком від 18 до 78 років, серед яких було 38 (42,22\%) чоловіків та $52(57,78 \%)$ жінки. Для визначення форм і тяжкості гострого перитоніту використовували класифікацію І.Ю. Полянського та співавторів [11]. Місцевий перитоніт виявлений у 12 (20\%) хворих, дифузний - у 15 (25), розлитий - у $17(28,33 \%)$, загальний - у 16 (26,67\%). Проведений ретроспективний аналіз 169 хворих на різні форми гострого перитоніту. У 79 з них були післяопераційні ускладнення, серед яких 24 випадки запалення і нагноєння рани, 5 - евентерацій, 14 - інтраабдомінальних інфільтратів і абсцесів, 18 - неспроможності кишкових швів, 18 триваючого перитоніту. Померли 39 хворих.

Лікування хворих проводили 3 використанням напрацьованого алгоритму (рис.1).

Результати дослідження. Основою вибору тактики $€$ створена нами прогностична шкала, що передбачає попередній i основний етапи прогнозування [12]. На першому етапі, до операції, у шкалу відібрані такі показники: характер основного захворювання і перитоніту, параметри класу коморбідної патології [13]. Згідно з шкалою виділяємо групи звичайного, збільшеного, середнього і високого ризику виникнення післяопераційних ускладнень. У хворих зі збільшеним ризиком протягом передопераційного приготування посилюємо антибактеріальну терапію. Перевагу надаємо препаратам комбінованої дії (Грандазол), що дозволяє збільшувати ефективність лікування без збільшення часу проведення приготування. 


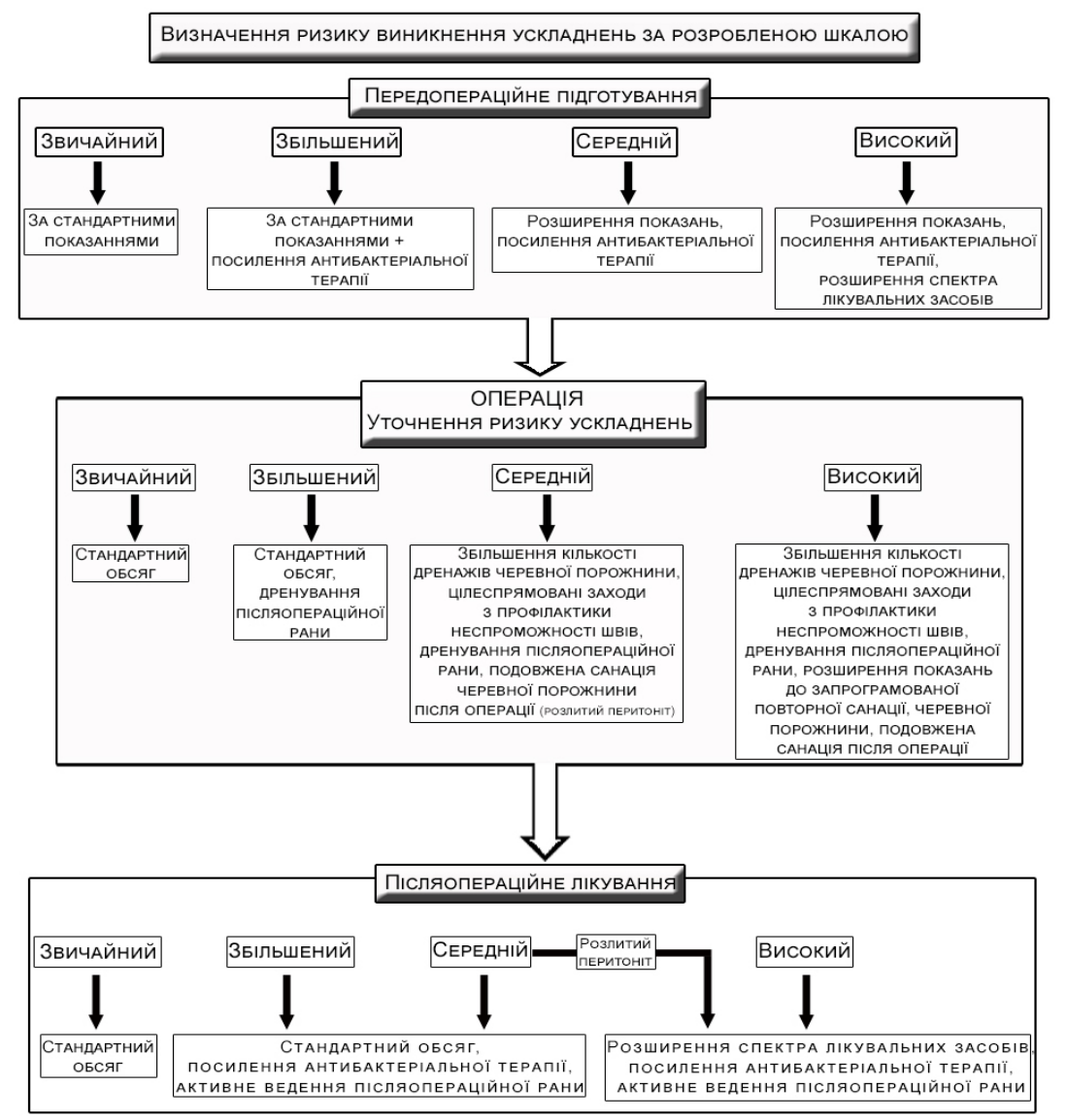

Рис. 1. Запропонований алгоритм лікування хворих на гострий перитоніт.

Хворим з середнім і високим ризиком передопераційне приготування проводимо навіть за відсутності стандартних показань. Для корекції водноелектролітних порушень застосовуємо розчин Рінгеpa.

Остаточне визначення ризику проводимо 3 урахуванням даних інтраопераційної ревізії та лабораторних досліджень. Основна шкала додатково містить показники кількості паличкоядерних нейтрофільних лейкоцитів i критерій застосування запрограмованих санацій, оскільки їх використання збільшує ризик розвитку ускладнень, насамперед, ранових. Підставою для включення таких критеріїв став ретроспективний аналіз даних хворих на гострий перитоніт.

Поширеність перитоніту оцінюємо за розробленим способом [14]. У хворих зі збільшеним ризиком застосовуємо активну профілактику ранових ускладнень. У хворих із середнім ризиком, окрім цього, використовуємо заходи з запобігання неспроможності швів, збільшуємо кількість дренажів очеревинної порожнини. У хворих з високим ризиком, попри це, розширюємо показання до запрограмованої санації очеревинної порожнини. Для санації використовуємо оригінальний метод і напрацьовані дренажно-санаційні системи [15], які дозволяють проводити пролонговану санацію після операції.

У післяопераційний період продовжуємо медикаментозне лікування, розпочате до операції, яке розширюємо призначенням засобів, що здатні покра- щувати мезентеріальний кровообіг, стимулювати перистальтичну активність кишок (Сорбілакт). За потреби, посилюємо антибактеріальну терапію, для чого часто використовуємо аміноглікозиди III покоління (Браксон). 3 урахуванням виявлених нами особливостей функційного стану печінки, нирок, механізмів фібринолізу, протеолізу, редокс-реакцій, у хворих з середнім і високим високим ризиком стандартний медикаментозний комплекс доповнюємо відповідними засобами. Це, зокрема, антиоксидантні й антипротеолітичні препарати, регулятори мікроциркуляції, гепатопротектори, нефропротектори. Перевагу надаємо препаратам комплексної дії (Даларгін, Лодиксем, Аргініну Глутамат, L-лізин, Tiотріазолін).

Обговорення результатів. Із використанням такої тактики нами проліковано 24 хворих, серед яких було 15 пацієнтів з розлитим і загальним гострим перитонітом, решта - 3 дифузним перитонітом. У всіх хворих з розлитим і загальним перитонітом використали запрограмовану санацію очеревинної порожнини.

Порівняльним дослідженням встановлено, що застосування напрацьованої тактики дозволило знизити на $18,18 \%$ частоту розвитку залишкових інтраабдомінальних інфільтратів у хворих на розлитий i загальний перитоніт, запобігти нагноєнням післяопераційної рани, уникнути летальності, скоротити тривалість стаціонарного лікування, в середньому, на 2,5 дні. У жодного хворого на дифузний гос- 
трий перитоніт не виникли інтраабдомінальні ускладнення.

\section{Висновки:}

1. Застосування розробленого алгоритму, що заснований на обгрунтованому виділенні груп ризику розвитку післяопераційних ускладнень, дозволяє визначати тактику лікування хворих і коректувати медикаментозний комплекс.

2. Напрацьована двоетапна прогностична шкала дозволяє обгрунтовано виділяти групи ризику виникнення ускладнень до хірургічного втручання і уточнювати ризик протягом операції.

3. Клінічна апробація алгоритму свідчить про його ефективність і доцільність наступного широкого впровадження в практику.

\section{References:}

1. Montravers P, Dupont H, Leone M, Constantin JM, Mertes PM, Laterre PF, et al. Guidelines for Management of Intra-Abdominal Infections. Anaesth Crit Care Pain Med. 2015; 34(2):117-30. doi: 10.1016/j.accpm.2015.03.005

2. Rhodes A, Evans LE, Alhazzani W, Levy MM, Antonelli M, Ferrer R, et al. Surviving Sepsis Campaign: International Guidelines for Management of Sepsis and Septic Shock: 2016. Intensive Care Med. 2017; 43(3):304-77. doi: 10.1007/s00134-017-4683-6

3. Sartelli M, Catena F, Abu-Zidan FM, Ansaloni L, Biffl WL, Boermeester MA, et al. Management of intraabdominal infections: recommendations by the WSES 2016 consensus conference World J Emerg Surg. 2017; 12:22. doi: 10.1186/s13017-017-0132-7

4. Mazuski JE, Tessier JM, May AK, Sawyer RG, Nadler EP, Rosengart MR, et al. The Surgical Infection Society Revised Guidelines on the Management of IntraAbdominal Infection. Surg Infect (Larchmt). 2017; 18(1):1-76. doi: 10.1089/sur.2016.261.

5. Fomin PD, Usenko OIu, Bereznytskyi YaS, editors. Nevidkladna khirurhiia orhaniv cherevnoi porozhnyny (standarty orhanizatsii ta profesiino oriientovani alhorytmy nadannia khirurhichnoi dopomohy) [Emergency abdominal surgery (standards of organization and professionally oriented algorithms for surgical care)]. Kyiv: Biblioteka Zdorov'ia Ukrainy; 2018. P.354. (in Ukrainian).

6. Muresan MG, Balmos IA, Badea I, Santini A. Abdominal Sepsis: An Update. J Crit Care Med (Targu Mures). 2018; 4(4):120-25. doi: 10.2478/jccm-20180023

7. Hecker A, Reichert M, Reuß CJ, Schmoch T, Riedel JG, Schneck E, et al. Intra-abdominal sepsis: new definitions and current clinical standards. Langenbecks Arch Surg. 2019; 404(3):257-71. doi: 10.1007/s00423-019-01752-7

8. Nguyen MP, Crotty MP, Daniel B, Dominguez Ed. An Evaluation of Guideline Concordance in the Management of Intra-Abdominal Infections. Surg Infect (Larchmt). 2019; 20(8):650-7. doi: 10.1089/sur.2018.317

9. Germer CT, Eckmann C. Peritonitis. Der Chirurg. 2016; 87(1):5-8. doi: 10.1007/s00104-015-0118-5
10. Ross JT, Matthay MA, Harris HW Secondary peritonitis: principles of diagnosis and intervention. BMJ. 2018; 361:k1407.doi: 10.1136/bmj.k1407

11. Polianskyi IIu, Grynchuk FV, Andriiets VV, Maksymiuk VV, Brodovskyi VV, Voitiv YaIu. Klasyfikatsiia hostroho perytonitu [Classification of acute peritonitis]. Klinichna anatomiia ta operatyvna khirurhiia. 2012; 11(2):68-70. doi: https://doi.org/10.24061/1727-0847.11.2.2012.16

12. Grynchuk AF, Polianskiy IYu, Grynchuk FV, Moroz PV. Two-stage prognosis of postoperative complications in patients with acute peritonitis. Practica Medicala. Romanian journal of medical practice. 2019; 14(3(67)):273-6. doi: 10.37897/RJMP.2019.3.16

13. Grynchuk FV. Nova shkala dlia otsiniuvannia komorbidnosti $\mathrm{V}$ nevidkladnii abdominalnii khirurhii [New scale for comorbidity assessment in emergency abdominal surgery]. Art of Medicine. 2018; 4(8):55-7. (in Ukrainian).

14. Grynchuk AF, Grynchuk FV, Polianskyi IIu. Ob'iektyvna diahnostyka poshyrenosti hostroho perytonitu [Objective diagnostics of the acute peritonitis spread]. Kharkivska khirurhichna shkola. 2017; $1: 31-4$.

15. Grynchuk AF, Grynchuk FV. Prolonhovana sanatsiia ocherevynnoi porozhnyny za hostroho perytonitu [A prolonged sanation of the peritoneal cavity in an acute peritonitis case]. Khirurhiia Ukrainy. 2017; 4(64), Dod.1:62-5.

\section{УДК 616.381-002-036.1-089-084 \\ ТАКТИКА ЛЕЧЕНИЯ БОЛЬНЫХ С ОСТРЫМ ПЕРИТОНИТОМ}

\section{А.В. Гринчук}

ВГУЗ Украины «Буковинский государственный медицинский университет», кафедра хирургии № 1, 2. Черновиьы, Украина, ORCID ID: 0000-0001-6636-6855, e-mail:grynchuk.andrii@bsmu.edu.ua

Резюме. Совершенствование тактики лечения больных с острым перитонитом (ОП) является актуальной проблемой вследствие высокой летальности.

Целью работы была предварительная оценка эффективности разработанной тактики лечения больных с ОП.

Материалы и методы. 60 больных, у которых местный ОП выявлен у 12 (20\%) больных, диффузный - у 15 (25), разлитый - у 17 (28,33\%), общий - у 16 (26,67\%). Ретроспективный анализ результатов лечения 169 больных различными формами ОП. У 79 из них были послеоперационные осложнения. Умерли 39 больных. Лечение больных проводили с использованием разработанного алгоритма.

Результаты. Основой выбора тактики была разработанная прогностическая шкала, предусматривающая предварительный и основной этапы прогнозирования. У больных со средним и высоким риском 
расширяем показания к предоперационной подготовке. Основную оценку проводим во время операции. Дифференцировано применяем комплекс интраоперационных и послеоперационных мероприятий. Расширяем показания к использованию мероприятий по профилактике осложнений, запрограммированных санаций брюшинной полости, применяем разработанные методы санации. С использованием такой тактики нами пролечено 24 больных. Снизилось на $18,18 \%$ количество интраабдоминальных инфильтратов. Сократилась на 2,5 дня продолжительность стационарного лечения. Не умер ни один больной.

Выводы. Применение разработанного алгоритма, основанного на выделении групп обычного, увеличенного, среднего и высокого риска развития осложнений, позволяет определять тактику лечения больных и корригировать медикаментозный комплекс. Клиническая апробация алгоритма свидетельствует о его эффективности и целесообразности последующего широкого внедрения в практику.

Ключевые слова: острый перитонит, прогнозирования осложнений, тактика лечения.

\section{UDC 616.381-002-036.1-089-084 \\ TREATMENT TACTICS OF PATIENTS WITH ACUTE PERITONITIS}

\section{A.F. Grynchuk}

Higher State Educational Establishment of Ukraine "Bukovinian State Medical University”, Department of Surgery № 1,

Chernivtsi City, Ukraine,

ORCID ID: 0000-0001-6636-6855,

e-mail: grynchuk.andrii@bsmu.edu.ua

Abstract. Due to the high mortality rate the treatment improvement of patients with acute peritonitis (AP) remains a critical problem. Nevertheless, a wellknown set of guidelines contains some contradictions that need to be resolved.

The aim of the work is to evaluate the effectiveness of the well-established treatment tactics of patients with AP.

Materials and methods. 60 patients with local AP were found in $12(20 \%)$ patients, diffuse - in 15 (25) patients, spilled-in $17(28.33 \%)$ patients, and total - in 16 (26.67\%) patients. A retrospective analysis of the treatment results of 169 patients with various forms of AP. 79 of them have had postoperative complications. 39 patients have died. Treatment of patients has been performed using the developed algorithm.
Results. The basis of the chosen tactics has been developed predictive scale, which provides the preliminary and main stages of prediction. The indications have been extended for patients of medium and high risk before the surgery. Patients with an average risk have a standard volume of it. We have provided additional measures to correct the state of regulatory mechanisms for patients with high risk. The main evaluation has been performed during the operation, taking into account the content of rod-shaped neutrophil leukocytes and a programmed abdominal debridement. The prevalence of AP has been estimated using the developed objective method. We have used a differentiated set of intraoperative and postoperative measures. The measures indications to prevent wound complications have been expanded for patients with increased risk. The measures to prevent intra-abdominal complications in patients with medium and high risk have been expanded either. The indications for the programmed abdominal debridement have been expanded for patients with high risk. The developed methods of debridement have been used. The standard medicated complex has been supplemented with appropriate means for patients with medium and high risk. The functional condition of the liver, kidneys, mechanisms of fibrinolysis, proteolysis, redox reactions has been taken into account in advance. The means are the following: antioxidant and antiproteolytic drugs, the regulators of the microcirculation, hepatoprotectors, nefroprotector. We treated 24 patients, including 15 patients with spilled and general AP with the help of these tactics, and the rest - with diffuse AP. A programmed lavage has been used to all patients having spilled and general AP.

A comparative research has proved that wellknown tactics allowed to decrease the residual intraabdominal infiltrates by $18.18 \%$ in patients with spilled and general peritonitis, prevent postoperative wound suppuration, avoid lethality, and reduce the duration of in-patient facility, on average, by 2.5 days. None of the patients with diffuse AP has had any intra-abdominal complications.

Conclusions. 1. The developed algorithm, based on a reasonable allocation of risk groups for postoperative complications, allows to determine the treatment tactics of patients and improve the medicated complex.

2 . The two-stage developed prognostic scale allows to identify risk groups for complications before surgery and specify the risk during the operation either.

3. Clinical testing of the algorithm indicates its effectiveness and proper implementation in further widespread practice.

Keywords: acute peritonitis, predicting complications, treatment tactics. 